\title{
第34回 日本泌尿器科学会群馬地方会演題抄録
}

\section{〈臨床症例 1 〉}

座長 田村 芳美（利根中央病院）

1. 精神遅帯症例に発症した腸腰筋濃瘍の 1 例 古谷 洋介, 小野 芳啓, 鈴木 和浩 山中 英壽 (群馬大院・医・泌尿器科) 武井 雄一, 芦名 孝一 (同 精神科) 鈴木 光一, 松尾 康滋, 矢嶋 久徳

(前橋赤十字病院)

症例は 21 歳, 男性. 多発性囊胞腎, 糖尿病, 膿腎症, 右 腸腰筋膿瘍と診断されたが, 精神発育遅帯とそれに伴う 強い入院拒否行動のため治療の継続が困難となったた め, 群大病院泌尿器科と精神科を紹介され受診した.

抗精神病薬の投与のもとに医療保護入院の措置をと り, 抗生物質, グロブリン製剤, インスリン投与を行った. 適切な精神科的対応のもとに保存的治療が奏功し, 約 3 週間の入院の後元気に退院した. 腸腰筋膿瘍は比較的稀 で重篤な疾患であるが, 治療 3 ケ月目の腹部 CT 検査で は完全に消失し良好な経過であった。

\section{2. 精巣と前立腺に転移を生じた悪性リンパ腫の 1 例}

大塚 保宏, 塩野 昭彦, 小林大志朗

町田 昌巳, 牧野 武雄, 柴山勝太郎

(公立富岡総合病院泌尿器科)
河野 真意

本間学
(浅間総合病院)

(公立富岡総合病院病理部)

70 歳男性, 主訴は左精巣無痛性腫大. 胃悪性リンパ腫 に対して胃全摘術の既往があった. 転移性または原発性 精巣腫瘍を疑い, 高位精巣摘除術を施行した. 病理結果 は malignant lymphoma, medium cell, B cell type であっ た. 他院の血液内科で化学療法と照射施行中, 排尿困難 が急速に出現した. CT 等の諸検査を施行したところ, 悪 性リンパ腫の前立腺転移を疑われたため, 当院で前立腺 生検を行なった. 病理の結果は以前と同じ malignant lymphoma, medium cell, B cell type であった.しかし, 同

\author{
日 時：平成 15 年 6 月 28 日 (土) \\ 場 所：群馬大学医学部刀城会館 \\ 会長: 小林 幹男 \\ 事 務 局: 柴田 康博
}

時に提出した免疫染色では Burkitt cell type との診断で あった。

\section{3. 石灰化と骨形成を伴った腎細胞癌の 1 例}

新井 誠二, 柏木 文蔵, 山本巧

深堀 能立, 鈴木 和浩, 山中 英壽

（群馬大学附属病院）

55 歳女性. 2003 年 3 月, 近医にて上腹部違和感の精査 で CT を施行し, 右腎下極に石灰化を認めた. 3 月 17 日, 精査加療目的に当科初診. 超音波検査では石灰化のため 詳細は不明で, KUB では L2 腰椎右側に石灰化病変を認 めた. CT では右腎下極に $4.3 \times 2.1 \mathrm{~cm}$ 大の石灰化を伴う 造影されない腫瘤を認めた. MRI では周囲脂肪組織への 浸潤が疑われた. AG では乏血管性の腫瘤を認めた. 以上 の画像診断から右腎悪性腫瘍との臨床的診断のもと, 5 月 13 日，右根治的腎摘除術を施行. 腫瘍は $4.0 \times 3.0 \times 3$. $0 \mathrm{~cm}$ 大で, 病理所見では石灰化と骨形成を伴う淡明型の 腎細胞癌を認めた. 以上より clear cell carcinoma, G1, pT1aN0M0 と診断した. 術後経過は良好で, 後療法は行 わず外来にて経過観察中.

\section{4. 膀胱平滑筋腫の 1 例}

\section{栗田 誠, 岡村 桂吾, 真下 透 \\ 斎藤 浩樹, 上原 尚夫, 篠崎 忠利}

(上毛泌尿器科記念善衆会病院)

患者は 44 歳女性. 不正出血を主訴に近医受診. 検査に て子宮筋腫と膀胱腫瘍を疑われ当院受診した. 膀胱鏡に て左尿管口部に球状の腫瘤を認めた. 血液検査などでは, 軽度の貧血を認める以外異常はなかった。

CT にて造影されない腫瘍を認め, 入院後 TUR-Btを 施行した. RP にては, 尿管との交通は認めず, 圧排所見 もなかった. 病理検査にて平滑筋腫の診断で, 術後後療 法せず，外来経過観察中である. 3r月後の膀胱鏡にては 再発は認めなかた. 膀胱平滑筋腫は稀な腫瘍であり, そ の病因などは, はっきりしない. 女性のほうが多くエス トロゲンの関与が示唆されている. ごくまれに再発の報 
告があり, 今後も経過観察が必要と思われる.

\section{〈臨床症例 2$\rangle$}

\section{座長 真下 透（善衆会病院）}

\section{5. 陰茎折症の 1 例}

武智 浩之, 松本 和久, 古作 望

（古作クリニック）

林雅道

(同 東分院)

小野 芳啓

(同 玉村分院)

症例は 19 歳, 男性. 主訴陰茎部痛. 本症例は元来, 陰 茎を陰茎根部方向へ押す (コキッコキッと音をたてる) 習慣があった. 平成 15 年 4 月 5 日, 起床時に普段と同様 に陰茎を押したところ,ブチッという断裂音とともに陰 茎部痛, 陰茎腫脹が出現し当院を受診. 来院時所見は, 陰 茎腹側に暗赤色の皮下出血を伴う陰茎の著明な腫脹を認 めた (排尿障害はなし). 来院後, 腫脹部を圧迫し, 止血剤 の投与を施行したが, 疼痛, 腫脹とも増大傾向にあった ため, 同日, 腰椎麻酔下に陰茎折症修復術を施行した. 断 裂音がした部位を露出できるように，包皮を環状切開し， 皮下直下の凝血塊を圧迫排出すると，陰茎海綿体に約 3 $\mathrm{mm}$ の白膜損傷を認め, 縫合修復した. 術後, 陰茎の屈曲, 変形を認めず, 切開部より遠位の陰茎皮膚に壊死も認め なかった。

\section{6.瘤切開にて着明な改善を認めた異所性尿管瘤の 1 例 西井昌弘, 鈴木 光一, 松尾 康滋 矢嶋 久徳 （前橋赤十字病院） 富田光 (足利赤十字病院)}

症例は 44 歳女性. 平成 14 年 11 月初旬より, 発熱・腹 満・肉眼的血尿市り近医受診. CT 上, 後腹膜多房性囊胞 と診断され, 当科紹介され初診. 精査にて左尿管瘤・左完 全重複腎孟尿管上半腎の水腎症と診断し, 精査加療目的 で当科入院. 身体所見に異常なし. 血液生化学検査・尿検 査に異常なし，膀胱鏡では膀胱頸部に至る尿管瘤あり， $\mathrm{RP}$ では上半腎の水腎に圧排された下半腎腎孟を認めた。 MRUrography では上半腎孟尿管の cobra-head 様の拡張 と著明な水腎症およびそのために圧排された下半腎を認 めた. 腰椎麻酔下に尿管瘤切開を施行, 約 $2500 \mathrm{ml}$ の混濁 尿が排泄された。術後水腎症は著明に改善した.VCGで I 度のVURを認めたが, UTI の合併なく現在外来経過 観察中である. 異所性尿管瘤とは, 瘤が膀胱頸部に及ぶ もの，あるいは膀胱頸部を越えて存在するものと定義さ れている. 瘤切開術は術後 VUR 合併の頻度が高いとし て敬遠されていたが, 侵襲性が少なく, 症例によっては 第一選択と成りうる治療法である.
7. 末梢血幹細胞移植併超大量化学療法と救済手術を 行った難治性精巣腫瘍の 2 例

小屋 智子, 森川 泰如, 斎藤 佳隆
内田 達也, 竹澤 豊, 小林 幹男

（伊勢崎市民病院）

大井 勝

(黒沢病院)

田村 芳美

（利根中央病院）

【症例 1】 22 歳男性. 左精巣腫瘍 (病理悪性奇形腫・臨床 病期III C) PEB3 コース後 $\beta \mathrm{HCG}, \mathrm{HCG}$ 正常化せず超大 量化学療法・後腹膜リンパ節郭清術施行. 術後マーカー 正常化. PEB2 コース後末梢血幹細胞採取 $(\mathrm{PBSCH})$ ・超 大量化学療法後末梢血幹細胞移植 (PBSCT) 施行. 肝転 移 $\mathrm{CR}$ ，後腹膜リンパ節，肺転移 PR.アジュバンド療法 (VIP1 コース) 施行.

【症例 2】32 歳男性. 右精巣腫瘍（病理胎児性癌，絨毛 癌, 臨床病期II B) PEB3 コース後, 後腹膜リンパ節郭清 術施行．その後 AFP 上昇，右総腸骨リンパ節転移認め VIP3 コース施行. AFP 正常化せず PBSCT 併用超大量 化学療法施行し AFP 正常化. 右総腸骨リンパ節 PR て総腸骨リンパ節廓清術施行. (病理成熟奇形腫)

【考 察】 2 症例共難治症例であったが PBSCT 併用超 大量化学療法が有効であった．近年化学療法後腫瘍マ一 カ一陽性例の一部に救済手術の有効性が報告され症例 1 はその一例と考えた。

\section{〈ビデオ〉}

\section{CAPD カテーテル位置異常に対する腹腔鏡下 CAPD カテーテル固定術}

岡本 亘平, 上井 崇智, 曲 友弘

川口拓也 （秩父市立病院）

柴田 康博, 羽鳥 基明, 鈴木 和浩

山中 英壽 (群馬大院・医・泌尿器科)

30 歳男性, $\operatorname{Ig}$ A 腎症. H6.1 月より血液透析開始. 同年 10 月 生体腎移植. H14.1 月再発性 IgA 腎症により血液透 析再開. 同年 10 月 CAPD へ移行. H15.1 月注排液不良が 出現し CAPD カテーテルの位置異常を認めたため同年 2. 6 亿腹腔鏡下 CAPD カテーテル固定術を施行した. 大 網に絡みついていた CAPD カテーテルを剥がし骨盤底 に吸収糸で固定した. CAPD カテーテル位置異常に対す る治療法としては，ガイドワイヤーを使用した方法が簡 便で侵襲が小さいが，本症例ではカール型の CAPD カ テーテルを使用していたためガイドワイヤーでの修正に は不適であった. 開腹術による入れ替えでは侵襲が大き くなるため, 今回は侵襲も小さく確実な方法である腹腔 鏡下手術を行った. 本法は低侵襲かつ確実であり有用な 方法であると考えられた。 


\section{〈臨床的研究 1$\rangle$}

座長 清水 信明（群馬県立がんセンター）

9. 伊勢崎市民病院泌尿器科における 5 年間の手術統計

（1998年 6 月～2003年5月）

野村 昌史, 関根 芳岳, 斎藤 佳隆

内田 達也, 竹澤 豊, 小林 幹男

（伊勢崎市民病院）

伊勢崎市民病院泌尿器科に抢ける過去 5 年間の手術統 計を報告する. 対象は 1998 年 6 月から 2003 年 5 月まで に手術を施行した症例 (ESWL は除く). 手術総数は 1998 年度 412 件, 1999 年度 473 件, 2000 年度 524 件, 2001 年 度 593 件, 2002 年度 704 件と年々増加傾向を認めた。こ の手術件数の増加は主として, 前立腺癌検診による前立 腺生検の増加と, それに伴う前立腺全摘徐術の増加によ るものであった (2002 年度の前立腺生検 295 件, 前立腺 全摘徐術 66 件). またその他の特徴としては, 腹腔鏡下手 術の増加がその適応の拡大に伴い認められた。

\section{2002 年度群馬県前立腺検診の結果と2003年度の実施} 状況

武智 浩之, 山本 巧, 大井 勝
坂西 理恵, 伊藤 一人, 久保田 裕
深堀 能立, 黒川 公平, 鈴木 和浩
山中 英壽 (群馬大院・医・泌尿器科)

2002 年度群馬県前立腺検診は 49 市町村で実施され, われわれの把握する 41 市町村では受診者 12,430 人に対 し, 168 症例 (1.35\%) 飞前立腺がん (初回受診者 $2.02 \%$, 再診者 $0.84 \%)$ が発見された. がんの発見率は年齢, PSA 值とも高いほど上昇する傾向にあった. PSA 単独検診と PSA・直腸診併用検診の比較では, 単独検診のほうが 1 次検診受診率は 8 倍高くなったが, 2 次検診受診率はや や低くなった。しかし，50歳以上男性人口に対するがん 発見率は 14 倍 PSA 単独検診のほうが高くなった. 基本 検診や他がん検診との併行検診では前立腺単独検診と比 較して 1 次検診受診率が 4.3 倍高くなったが，2 次検診 受診率は低くなった. しかし，50 歳以上男性人口に対す るがん発見率は併行検診のほうが 2.3 倍高くなった。 2003 年度は群馬県下 70 市町村中 54 市町村 $(77 \%)$ で検 診は実施されている。内訳は前立腺単独検診 11 市町村 (直腸診併用 4 市町村), 他がん検診と併行検診 3 市町村, 基本検診と同時実施 30 市町村，各自治体で独自に実施 10 市町村となっている.
11. 群馬県における前立腺癌の疫学特性

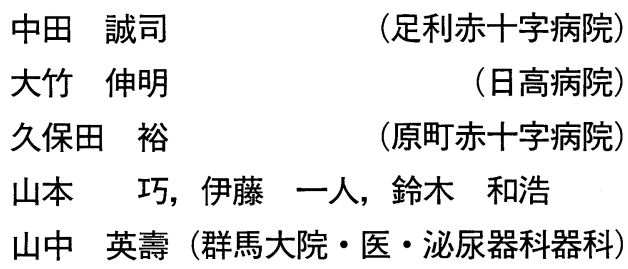

【目 的】 日本では, 前立腺癌の数は急激に増加してい る. 今回, 群馬県に扔ける前立腺癌の疫学特性について 検討した。

【対象と方法】群馬大学では，1985 年より前立腺癌の登 録を開始した.これより, 群馬県の前立腺癌の罹患数, 罹 患率, 年齢別罹患率, 病期, 分化度について検討した。

【結 果】年代, 年齢とともに罹患数, 罹患率は着実に 増加した. 年代とともに病期 A, D が減り, B, C が増加し た. 分化度には年代による変化はなかった。

【結 語】 群馬県の前立腺癌は増加しつつある. PSA 検 診などで早期発見に努め, 死亡率の低下につなげること が重要である。

\section{〈臨床的研究 $2 〉$}

座長 竹澤 豊（伊勢崎市民病院）

12. 多系統萎縮症 (MSA) における排尿機能の臨床的検 討

$\begin{array}{llrl}\text { 曲 } & \text { 友弘. 深堀 } & \text { 能立. 鈴木 } & \text { 和浩 } \\ \text { 山中 } & \text { 英壽 } & \text { (群馬大学附属病院) } \\ \text { 小倉 } & \text { 治之 } & \text { (黒沢病院泌尿器科) }\end{array}$

【始めに】MSA における排尿障害の特徴について，下 部尿路症状の出現時期に着目して検討した.

【対象と方法】UDS を施行した 20 例 (OPCA11, SDS5, SND4) を対象とした。年齢は 39-74 (中央值 61.5) 歳で, 性別は男 12 例, 女 8 例であった。

【結 果】神経内科的診断確定までに下部尿路症状が出 現したのは 85\%で，内訳は，OPCA82\%，SDS80\%， SND100\%であった，下部尿路症状を初発症状としたの は 6 例 (30\%) で, SDS 3 例 (60\%), OPCA 2 例 (19\%), SND1 例 (25\%), 下部尿路症状単独発症は 3 例 (15\%) で, SDS 2 例, OPCA 1 例であった. 初発症状から下部尿路症 状発症までの期間は 0-4 年 (中央值 1 年), 内訳は OPCA 0-4 年 (中央值 2 年), SDS 0-0.5 年 (中央值 0 年) SND 0 -1 年 (中央值 1 年) であった.

【まとめ】下部尿路症状で発症する症例が一定の割合で 存在し, 泌尿器科一般診療において留意すべきであると 考元られた。 
13. 組織好酸球浸潤は表在性膀胱がんの再発危険因子で ある

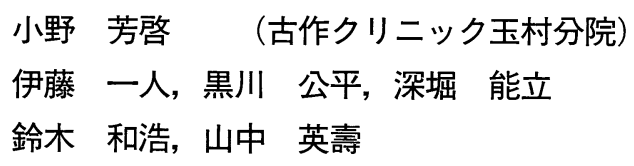

【目 的】組織好酸球浸潤 (TATE) と膀胱がんの再発 との関連を明らかにする。

【対象と方法】表在性膀胱がんの男性新鮮例を TATE の有無により二群に分け，排尿症状と非再発率を比較す る.一視野中 10 個以上を TATE 陽性とし, 排尿症状は国 際前立腺スコア (I-PSS) を, 非再発率曲線は KaplanMeier 法を用いた

【結 果】 TATE 陽性群で排尿症状が悪い傾向があっ たが有意でなかった。非再発率は 2 年， 5 年でそれぞれ 90.9\%，75.8\% (TATE 陰性群 12 例)， 60.0\%，32.0\% (TATE 陽性群 10 例) で, TATE 陽性群で有意に悪かっ た $(\mathrm{p}=0.0273)$. TATE は独立した再発危険因子であるこ とが示唆された.

\section{〈連絡事項〉}

前立腺癌骨転移に対するサマリウムによる治療について 鈴木 和浩

(群馬大学)

〈シンポジウム〉

座長 深堀 能立 (群馬大学)

『不妊治療における産婦人科領域と泌尿器科領域の連 携』

（1）婦人科領域における現状と問題点 伊藤 理廣群馬大院・医・婦人科)

（2）泌尿器科領域における現状と問題点 柴田 康博 (群馬大院・医・泌尿器科) 